\section{Ultraviolet-B Radiation Damage on Kentucky Bluegrass II: Hormone Supplement Effects}

\author{
Erik H. Ervin, ${ }^{1}$ Xunzhong Zhang, ${ }^{2}$ and John H. Fike ${ }^{1}$ \\ Department of Crop and Soil Environmental Sciences, Virginia Polytechnic \\ Institute and State University, Blacksburg, VA 24061-0404
}

Additional index words. alpha-tocopherol, antioxidant enzyme activity, chlorophyll fluorescence, humic acid, photochemical efficiency, salicylic acid, seaweed extract

\begin{abstract}
High ultraviolet-B (UV-B; $290-320 \mathrm{~nm}$ wavelength) radiation may significantly contribute to the quality decline and death of kentucky bluegrass (Poa pratensis L.) sod during summer transplanting. Antioxidants and protective pigments may be involved in plant defense against oxidative stress caused by UV-B. Selected exogenous hormones may alleviate UV-B damage by upregulating plant defense systems. The objectives of this study were to determine if exogenous hormone or hormone-like substances could alleviate UV-B damage to 'Georgetown'kentucky bluegrass (Poa pratensis $\mathbf{L}$.) under greenhouse conditions. The hormone salicylic acid at $150 \mathrm{mg} \cdot \mathrm{m}^{-2}$ and the hormone-containing substances, humic acid (HA) at $150 \mathrm{mg} \cdot \mathrm{m}^{-2}$ and seaweed extract (SWE) at $50 \mathrm{mg} \cdot \mathrm{m}^{-2}$, were applied to plugs of kentucky bluegrass and then subjected to UV-B radiation $\left(70 \mu \mathrm{mol} \cdot \mathrm{m}^{-2} \cdot \mathrm{s}^{-1}\right)$. The UV-B irradiation stress reduced turf quality by $51 \%$ to $66 \%$ and photochemical efficiency by $63 \%$ to $68 \%$ when measured 10 or 12 days after initiation of UV-B. Endogenous alpha-tocopherol (AT) and antioxidant enzymes (superoxide dismutase (SOD) and catalase) were reduced by UV-B stress. Anthocyanin content was increased from day 1 to 5 and then decreased from day 5 to 10 of continuous UV-B irradiation. Application of SA and HA + SWE enhanced photochemical efficiency by $86 \%$ and $82 \%$, respectively, when measured 10 or 12 days after UV-B initiation. In addition, application of the hormonal supplements increased AT concentration, SOD, catalase activity, and anthocyanin content when compared to the control at 10 days after UV-B initiation. Bluegrass with greater AT concentration and SOD and catalase activity exhibited better visual quality under UV-B stress. The results of this study suggest that foliar application of SA and HA + SWE may alleviate decline of photochemical efficiency and turf quality associated with increased UV-B light levels during summer.
\end{abstract}

The vagaries of the turfgrass and landscaping industry often dictate that kentucky bluegrass sod be harvested, transported, and transplanted during the summer. Frequently, increased respiratory heating during storage, transport, and subsequent exposure to high UV-B during transplanting can cause shock (Giese et al., 1997). The shock often results in bleached, inactive turfgrass leaves. Plants better adapted to resist UV-B induced photo-bleaching usually contain more robust screening (pigment) and scavenging (antioxidant) protection systems (Mackerness, 2000). Resistance to UV-B damage most likely involves both avoidance and tolerance mechanisms.

Day et al. (1992) noted conifers are efficient avoiders of UV-B damage due to higher needle levels of flavonoid and related phenolic pigments (anthocyanins) that strongly absorb UV and transmit nondamaging longer wavelengths. Most herbaceous species do not

\footnotetext{
Received for publicatio 14 Apr. 2003. Accepted for publication 31 Dec. 2003. This Research was conducted as part of USDA-CSREES project no. VA-135660. Mention of a trademark, proprietary product, or vendor does not constitute a guarantee or warranty of the product by Virginia Tech or the U.S. Dept. of Agriculture and does not imply its approval to the exclusion of other products or vendors that also may be suitable.

${ }^{1}$ Assistant professor.

${ }^{2}$ Research scientist.
} However, it has been established that exposure of herbaceous plants to UV radiation will up-regulate the formation of flavonoids (Salisbury and Ross, 1991). Additionally, application of a green-pigmented colorant that strongly absorbs in the UV range (250 to 400 $\mathrm{nm}$ ) has been shown to improve avoidance of UV-B damage in kentucky bluegrass (Ervin et al., 2004) and creeping bentgrass (Agrostis stolonifera L.; Schmidt and Zhang, 2001). Further, by exogenously applying ascorbic acid and alpha-tocopherol, endogenous alphatocopherol and antioxidant enzyme activities increased and directly correlated with greater tolerance of UV-B by kentucky bluegrass (Ervin et al., 2004).

Greater tolerance to oxidative stress caused by high UV-B may involve hormonal signals to up-regulate antioxidant enzyme activity. One of the implicated hormones is the phenolic compound, salicylic acid (SA). Numerous studies have shown that SA is a key signaling compound involved in the activation of certain plant defense mechanisms including induction of pathogenesis-related genes and antioxidant enzymes (Mackerness, 2000; Jordan, 1996). Recently, Clarke et al. (2002) noted that SA reduced heat-induced oxidative damage and increased catalase, glutathione reductase and peroxidase activity in Phaseolus vulgaris. Sanjay et al. (2001) indicated SA increased peroxidase activity and phenolic content in Pisum sativum. Exogenous application of SA reduced visual injury and loss of photochemical efficiency of kentucky bluegrass and creeping bentgrass under UV-B stress (Schmidt and Zhang, 2001).

It has been documented that application of alkaline extracts of the seaweed Ascophyllum nodosum Jol. (SWE), in combination with acid extracts of the humic acid (HA) component of leonardite enhanced antioxidant activity (Zhang and Schmidt, 1999), photochemical efficiency (Zhang et al., 2003), and improved resistance to UV-B induced damage in kentucky bluegrass (Schmidt and Zhang, 2001). This SWE source contains $\approx 70 \mathrm{mg} \cdot \mathrm{kg}^{-1}$ of the cytokinin, zeatin riboside (Zhang and Ervin, 2004). Higher cytokinin levels in tissues undergoing abiotic stress have been associated with greater antioxidant enzyme activities resulting in less photosynthetic damage (Liu and Huang, 2002). Numerous HA sources have been shown to contain indole acetic acid (IAA) and exhibit auxin-like activity (Canellas et al., 2002; Muscolo et al., 1998; O'Donnell, 1973). Increased endogenous amounts of cytokinins and auxins have been associated with membrane stabilization leading to protection of photosynthetic activity during osmotic and temperature stress (Nooden and Leopold, 1988; Aldesuquy, 2000).

Given this evidence, our hypothesis was that application of SA or HA + SWE, before UV$\mathrm{B}$ exposure, would up-regulate plant defense mechanisms resulting in greater tolerance of kentucky bluegrass to UV-B. Our objectives were to determine if these substances would improve endogenous antioxidant concentrations and antioxidant activities in kentucky bluegrass and be associated with greater UV-B tolerance as determined by photochemical efficiency, visual quality, and pigment content responses.

\section{Materials and Methods}

The detailed experimental procedures, including field growth conditions of harvested plant material, subsequent greenhouse growing conditions, UV-B treatments, data collection, measurement, and statistical protocols were described in a companion paper (Ervin et al., 2004).

Experiment 1. Treatments for this study were 1) $\mathrm{SA}$ at $\left.150 \mathrm{mg} \cdot \mathrm{m}^{-2}, 2\right) \mathrm{HA}$ at 150 $\mathrm{mg} \cdot \mathrm{m}^{-2}+\mathrm{SWE}$ at $50 \mathrm{mg} \cdot \mathrm{m}^{-2}$, and 3) control. Three replications were arranged in randomized complete blocks on the greenhouse bench. Salicylic acid (Research Organics; Cleveland, Ohio), seaweed extract (Acadian Seaplants Limited, Dartmouth, Nova Scotia, Canada) and HA (Plant Wise Biostimulants, Inc. Louisville, Ky.) are each available as dry powders. Solutions were made by mixing the products with water. Salicylic acid solution required addition of a surfactant (Aqua-Gro, Aquatrols Corporation, Cherry Hill, N.J.) at $0.05 \%$ to encourage uniform coverage.

Light absorbance of the two treatment solutions was measured across the UV spectral range ( 250 to $400 \mathrm{~nm}$ ) and results are presented as percent absorbance at each wavelength (Fig. 1). The SA-treatment solution had 20\% 


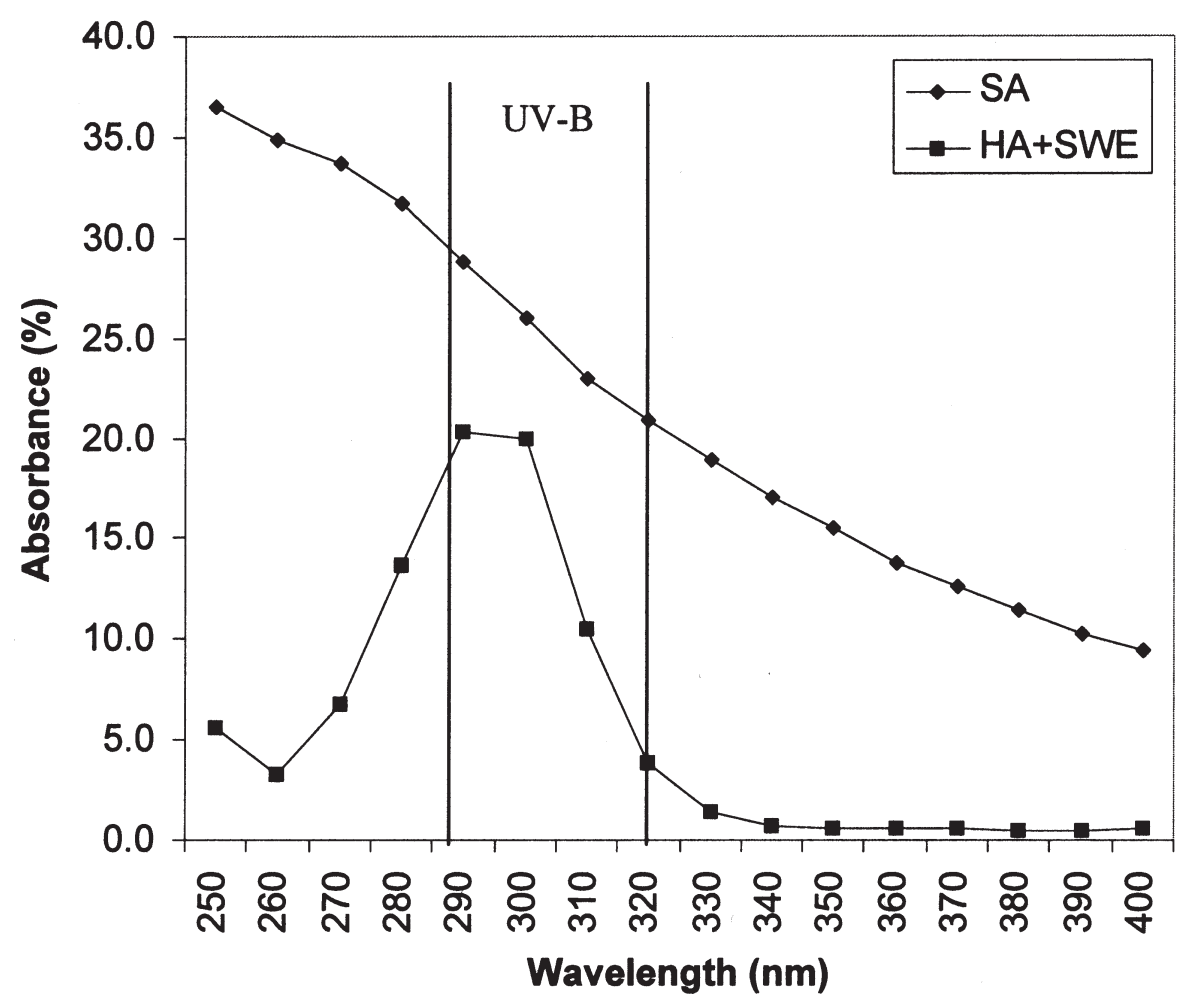

Fig. 1. Ultraviolet (250 to $400 \mathrm{~nm}$ ) absorbance characteristics of the supplements used in this study.

to $30 \%$ absorbance across the UV-B spectra, while maximum absorbance of $20 \%$ occurred at 290 to $300 \mathrm{~nm}$ for the HA + SWE solution. The treatments were sprayed onto kentucky bluegrass foliage using $60-\mathrm{mL}$ syringes with needles on 15 Mar. 2001. The treated turfgrass was not irrigated for $24 \mathrm{~h}$.

Twenty-four hours after treatment the plugs were placed under artificial UV-B radiation (70 $\mu \mathrm{mol} \cdot \mathrm{m}^{-2} \cdot \mathrm{s}^{-1}$ ) provided by three $40-\mathrm{W}$ UV-B fluorescent lamps (UVB-313, Cleveland, Ohio). The plugs were spaced evenly $(2.5 \mathrm{~cm})$, kept $0.5 \mathrm{~m}$ below the UV-B source, and grown under continuous UV-B in a greenhouse maintained at $22 \pm 2{ }^{\circ} \mathrm{C}$. Daylength averaged $11 \mathrm{~h}$. Plugs were subjected to UV-B from 16 to $26 \mathrm{Mar}$. and irrigated three times a week to prevent moisture stress. On 27 Mar., the plugs were removed from UV-B treatment and placed under a mist system for recovery. Photochemical efficiency and turf quality (based on a visual scale of 1 to 9 , with 9 indicating the best quality) scores (as an indication of the degree of visual injury or lack thereof) were determined as in previous trials.

Experiment 2. Treatments remained the same as in Expt. 1. The plugs were treated on 31 May and then placed under continuous UVB irradiation from 1 through 12 June 2001. On 13 June, UV-B treatment ceased and the plugs were set under a mist system for recovery. Photochemical efficiency and turf quality scores were determined as in previous trials.

Experiment 3. Treatments remained the same as those in Expts. 1 and 2. However, there were four replications instead of three. The plugs were treated on 24 Jan. 2002 and placed under continuous UV-B from 25 Jan. through 4 Feb. 2002. On 5 Feb., UV-B irradiation stress was discontinued and the plugs were placed under a mist system for recovery. the general linear models procedure in the tistical Analysis System (SAS Institute, 1990).
${ }^{\mathrm{y}} \mathrm{HA}=$ humic acid; SWE = seaweed extract.
Factor one included three levels of supplement treatments and factor two included three levels of experimental time periods (i.e., Expts. 1, 2, and $3)$. Supplement $\times$ experiment interactions were nonsignificant for three of four sampling dates, therefore, quality and photochemical efficiency data are presented as means analyzed over all three experimental periods. Mean differences were ascertained using Fisher's protected $1 \mathrm{sd}$ $(P=0.05)$.

\section{Results}

All kentucky bluegrass plants began the trials with equivalent photochemical efficiency and similar visual quality (Table 1). Exposure of kentucky bluegrass to UV-B caused a rapid decline in photochemical efficiency and quality regardless of treatment. However, following 4 or $5 \mathrm{~d}$ of continuous UV-B, photochemical efficiencies of plants treated with $\mathrm{HA}+\mathrm{SWE}$ and SA were greater than the control by $29 \%$ and $21 \%$, respectively. At 10 or $12 \mathrm{~d}$ of exposure, SA-treated bluegrass had 33\% higher photochemical efficiency, while HA + SWE-treated bluegrass had $42 \%$ greater photochemical efficiency. At the end of a recovery period ( 28 or $42 \mathrm{~d}$ ), only the SA-treated plants continued to exhibit greater photochemical efficiency.

Similar to the photochemical efficiency results, visual quality was greater due to HA + SWE treatment at all sample dates after exposure to UV-B (Table 1); SA had positive effects on visual quality at the 10 to $12 \mathrm{~d}$ rating periods. Following UV-B removal, both treatments provided greater recovery of visual quality. When averaged over all sample dates and experiments, photochemical efficiency readings were positively correlated $\left(r=0.77^{* * *}\right)$ with quality ratings, providing good confidence for our visual assessments of turfgrass injury or recovery.

Leaf tissue samples for antioxidant analyses were only collected during the third experimental trial. One day after UV-B initiation, AT leaf concentration was equivalent across all treatments (Table 2). However, at day 5, HA + SWE treated bluegrass had higher endogenous AT levels relative to the control. At day 10, the $\mathrm{SA}$ and $\mathrm{HA}+\mathrm{SWE}$ treatments resulted in AT concentrations that were $40 \%$ to $43 \%$ higher than the control. Higher visual quality ratings were correlated with greater endogenous AT concentrations over the 10-d treatment period due to exogenous treatments of HA $+\operatorname{SWE}(r$ $\left.=0.96^{* *}\right)$ or SA $\left(r=0.69^{*}\right)$.

Table 1. Quality and Photochemical Efficiency responses of kentucky bluegrass to UV-B irradiation and hormone supplement treatment analyzed over three experimental periods

\begin{tabular}{lcccc}
\hline & \multicolumn{4}{c}{ Day } \\
\cline { 2 - 5 } Supplement & 1 & 4 or 5 & 10 or 12 & 28 or 42 \\
\hline \multirow{2}{*}{ Control } & $0.60 \mathrm{a}^{\mathrm{z}}$ & Photochemical efficiency (Fv/Fm) & $0.36 \mathrm{~b}$ \\
HA + SWE & $0.64 \mathrm{a}$ & $0.34 \mathrm{~b}$ & $0.14 \mathrm{~b}$ & $0.40 \mathrm{~b}$ \\
Salicylic acid & $0.63 \mathrm{a}$ & $0.48 \mathrm{a}$ & $0.21 \mathrm{a}$ & $0.53 \mathrm{a}$ \\
& & $0.43 \mathrm{a}$ & $0.24 \mathrm{a}$ & $5.4 \mathrm{~b}$ \\
Control & $8.8 \mathrm{a}$ & Quality $(1=$ dead; $9=$ ideal $)$ & $2.9 \mathrm{~b}$ & $6.7 \mathrm{a}$ \\
HA + SWE & $8.9 \mathrm{a}$ & $5.6 \mathrm{~b}$ & $4.1 \mathrm{a}$ & $7.4 \mathrm{a}$ \\
Salicylic acid & $8.9 \mathrm{a}$ & $6.6 \mathrm{a}$ & $4.4 \mathrm{a}$ & $5.7 \mathrm{~b}$
\end{tabular}

${ }^{2}$ Values within the same column marked with same letters are not different significantly at $\alpha=0.05$. 
Table 2. Kentucky bluegrass antioxidant and pigment responses to hormone supplement treatments and UV-B irradiance over 10 d; Expt. 3

\begin{tabular}{lcccc}
\hline Supplement & Rate & \multicolumn{3}{c}{ Days of UV-B exposure } \\
\cline { 3 - 5 } treatment & $\left(\mathrm{mg} \cdot \mathrm{m}^{-2}\right)$ & 1 & 5 & 10 \\
\hline & & & Alpha-tocopherol $\left(\mu \mathrm{g} \cdot \mathrm{g}^{-1} \mathrm{FW}\right)$ & \\
Control & 0 & $6.4 \mathrm{a}^{\mathrm{y}}$ & $4.0 \mathrm{~b}$ & $2.4 \mathrm{~b}$ \\
HA + SWE & $150+50$ & $6.9 \mathrm{a}$ & $5.9 \mathrm{a}$ & $4.0 \mathrm{a}$ \\
Salicylic acid & 150 & $5.8 \mathrm{a}$ & $4.6 \mathrm{ab}$ & $4.2 \mathrm{a}$ \\
& & & SOD activity (unit/mg protein $)$ & \\
Control & 0 & $17.2 \mathrm{a}$ & $15.1 \mathrm{~b}$ & $10.7 \mathrm{~b}$ \\
HA + SWE & $150+50$ & $17.5 \mathrm{a}$ & $18.2 \mathrm{a}$ & $15.9 \mathrm{a}$ \\
Salicylic acid & 150 & $19.9 \mathrm{a}$ & $21.6 \mathrm{a}$ & $16.7 \mathrm{a}$ \\
& & & Catalase activity $($ unit/mg protein $)$ & \\
Control & 0 & $84.5 \mathrm{~b}$ & $44.5 \mathrm{c}$ & $18.8 \mathrm{~b}$ \\
HA + SWE & $150+50$ & $85.5 \mathrm{~b}$ & $55.8 \mathrm{~b}$ & $45.3 \mathrm{a}$ \\
Salicylic acid & 150 & $117.5 \mathrm{a}$ & $77.1 \mathrm{a}$ & $45.6 \mathrm{a}$ \\
& & & APX activity $\left(\mathrm{unit} / \mathrm{mg} \mathrm{protein}^{\mathrm{y}}\right)$ & \\
Control & 0 & $0.5 \mathrm{a}$ & $0.5 \mathrm{a}$ & $0.5 \mathrm{a}$ \\
HA + SWE & $150+50$ & $0.7 \mathrm{a}$ & $0.6 \mathrm{a}$ & $0.7 \mathrm{a}$ \\
Salicylic acid & 150 & $0.7 \mathrm{a}$ & $0.9 \mathrm{a}$ & $1.0 \mathrm{a}$ \\
& & & Total Chlorophyll $\left(\mu \mathrm{g} \cdot \mathrm{mL}^{-1}\right)$ & \\
Control & 0 & $13.4 \mathrm{~b}$ & $6.5 \mathrm{a}$ & $2.8 \mathrm{~b}$ \\
HA + SWE & $150+50$ & $13.3 \mathrm{~b}$ & $8.6 \mathrm{a}$ & $5.6 \mathrm{a}$ \\
Salicylic acid & 150 & $15.3 \mathrm{a}$ & $8.2 \mathrm{a}$ & $5.0 \mathrm{a}$ \\
& & & Total Carotenoids $\left(\mu \mathrm{g} \cdot \mathrm{mL}^{-1}\right)$ & \\
Control & 0 & $2.7 \mathrm{~b}$ & $1.3 \mathrm{a}$ & $0.7 \mathrm{~b}$ \\
HA + SWE & $150+50$ & $2.6 \mathrm{~b}$ & $1.7 \mathrm{a}$ & $1.5 \mathrm{a}$ \\
Salicylic acid & 150 & $2.9 \mathrm{a}$ & $1.5 \mathrm{a}$ & $1.2 \mathrm{a}$ \\
& & & Anthocyanin $\left(\mathrm{A}^{530}-\left(0.25 \times \mathrm{A}^{657}\right)\right)$ & \\
Control & 0 & $0.28 \mathrm{~b}$ & $0.45 \mathrm{~b}$ & $0.23 \mathrm{~b}$ \\
HA + SWE & $150+50$ & $0.34 \mathrm{~b}$ & $0.45 \mathrm{~b}$ & $0.42 \mathrm{a}$ \\
Salicylic acid & 150 & $0.56 \mathrm{a}$ & $0.61 \mathrm{a}$ &
\end{tabular}

${ }^{2} \mathrm{HA}=$ humic acid; SWE $=$ seaweed extract.

yValues within the same column marked with same letters are not different significantly at $\alpha=0.05$. ${ }^{\mathrm{x}} \mathrm{SOD}=$ superoxide dismutase; $\mathrm{APX}=$ ascorbate peroxidase .

Superoxide dismutase activity was equivalent across treatments at day 1 (Table 2). At day 5, SA-and HA + SWE-treated plants had greater SOD activity. From day 1 to 10 , SOD activity decreased by $38 \%$ in control plants, while SA- and HA + SWE-treated plants only lost $16 \%$ and 9\% SOD activity, respectively. Correlation between turf quality and SOD activity was not significant over the 10-d period.

Catalase activity declined sharply following $5 \mathrm{~d}$ of UV-B irradiation (Table 2). However, relative to the control, bluegrass pretreated with HA + SWE or SA maintained $25 \%$ and $73 \%$ higher catalase activity, respectively, at 5 $\mathrm{d}$ after UV-B initiation. When measured at 10 $\mathrm{d}, \mathrm{HA}+\mathrm{SWE}$ or SA resulted in 2.4-fold greater catalase activity. Accordingly, HA + SWE $(r$ $\left.=0.97^{* *}\right)$ and SA $\left(r=0.78^{* *}\right)$ were correlated with greater quality ratings over the 10-d UV-B exposure period. Ascorbate peroxidase activity was unaffected by UV-B irradiation and supplement pretreatment (Table 2).

Greater total chlorophyll content (i.e., chl $\mathrm{a}+\mathrm{b}$ ) remained following $10 \mathrm{~d}$ of UV-B due to HA + SWE and SA (Table 2); both treatments also resulted in greater carotenoids at day 10. Anthocyanin content for all three treatments increased under continuous UVB from day 1 to 5 , and decreased from day 5 to d 10 (Table 2). Relative to the control, SA-treated bluegrass had greater anthocyanin concentrations at all sampling dates, while HA + SWE plants had greater anthocyanin only at day 10. Patterns of anthocyanin concentration suggest control plants had less ability to maintain this defense with prolonged exposure to UV-B radiation. al., 2001) and many species have been noted to up-regulate anthocyanin production in response to increased UV radiation (Holton and Cornish, 1995). In general, hormone-supplement treated plants maintained greater overall pigment concentrations over the 10-d irradiation period. Less pigment destruction was most likely associated with the more robust antioxidative protection systems reported herein due to HA + SWE and SA treatments.

The hormone-like activities of seaweed extract and humic acid have been identified with bioassay and GC-MS techniques (Cacco and Dell'Agnola, 1984; Sanderson et al., 1987; Yan, 1993). Indirect ELISA indicates that the SWE used in these experiments contained 70 $\mathrm{mg} \cdot \mathrm{kg}^{-1}$ of the cytokinin, zeatin riboside (Zhang and Ervin, 2004). Applications of a combination of SWE and HA have been previously shown to increase antioxidant concentrations and activities of drought-stressed kentucky bluegrass (Zhang and Schmidt, 1999). Our results also indicate that antioxidant increases are correlated with reduced UV-B irradiation damage. Based on our reading of the literature, it is possible that the SWE + HA treatment affected cell membrane integrity either directly, by altering membrane components, or indirectly, by increasing antioxidative protective mechanisms. Yan et al. (1997) reported that perennial ryegrass (Lolium perenne L.) pretreated with SWE fortified with $\mathrm{HA}$ and $\mathrm{Fe}$ had increased drought tolerance associated with increased membrane fluidity (i.e., greater levels of unsaturated fatty acids). It is also clear that cytokinins directly function to scavenge free radicals and prevent their formation (Leshem, 1981; Musgrave, 1994). A further role of cytokinins in antioxidative protection has recently been shown by Liu and Huang (2002) who reported that treatment of creeping bentgrass roots with zeatin riboside reduced lipid peroxidation and senescence of leaves exposed to high temperature stress by suppressing loss of SOD and catalase activity.

In summary, our data indicate that increasing the robustness of the antioxidative protection system in kentucky bluegrass through the application of phytohormone supplements prior to UV-B stress served to mitigate pigment destruction, alleviate decline of photochemical efficiency, delay senescence, and improve the rate of visual quality recovery. As terrestrial UV-B levels continue to increase, our approach of boosting plant defense systems through direct application of antioxidants (Ervin et al., 2004) or application of hormone supplements may prove of high utility for improving the abiotic stress resistance of cool-season turfgrasses. However, further research is required to confirm our results in field environments and fine-tune application protocols.

\section{Literature Cited}

and activity of antioxidant enzymes such as ascorbate peroxidase and SOD (Mackerness, 2000; Jordan, 1996).

Our results indicate increased anthocyanin content for all treatments following $5 \mathrm{~d}$ of UV-B irradiation, with SA-treated bluegrass having the highest concentration. Anthocyanins are reported to function in preventing photooxidative damage as leaves senesce (Field et
Abdou, E., Abd-Alla, H.M., and A.A. Galal. 2001. Survey of sesame root rot/wilt disease in Minia and their possible control by ascorbic acid and salicylic acid. Austral. J. Agr. Sci. 32:135-152.

Aldesuquy, H.S. 2000. Effect of indol-3-yl-acetic acid on photosynthetic characteristics of wheat flag leaf during grain filling. Photosynthetica 38(1):135-141. 
Basra, R.K. and A.S. Basra. 2001. Phenolic biosynthesis inhibitors accentuate the effects of heat-shock injury in mung bean seedlings: Alleviation by salicylic acid. J. New Seeds 3:41-49.

Bowler, C., T. Alliote, M. Van Montagu, and D. Inze. 1989. The induction of manganese superoxide dismutase in response to stress in Nicotiana plumbaginifolia. EMBO J. 8:31-38.

Brabdle, J.R., W.F. Campbell, W.B. Sisson, and M.M. Caldwell. 1977. Net photosynthesis, electron transport capacity and ultrastructure of Pisum sativum L. exposed to ultraviolet-B radiation. Plant Physiol. 60:165-169.

Cacco, G., and G. Dell'Agnola. 1984. Plant growth regulator activity of soluble humic complex. Can. J. Soil Sci. 64:225-228.

Caldwell, M.M., R. Robberecht, and S.D. Flint. 1983. Internal filters: Prospects of UV-acclimation in higher plants. Phys. Planta. 58:445-450.

Cannellas, L.P., F.L. Olivares, A.L. OkorokovaFacanha, and A.R. Facanha. 2002. Humic acids isolated from earthworm compost enhance root elongation, lateral root emergence, and plasma membrane $\mathrm{H}^{+}$-ATPasa activity in maize roots. Plant Physiol. 130:1951-1957.

Chance, B. and A.C. Maehly. 1955. Assay of catalase and peroxidases. Methods Enzymol. 2:764-775.

Clapp, C.E., R. Liu, V.W. Cline, Y. Chen, and M.H.B. Hayes. 1998. Humic substances for enhancing turfgrass growth, p.227-234. In: G. Davies and E. A. Ghabbour(eds.).Humic substances: Structures, properties and uses. Royal Soc. Chem. Publ., Cambridge, U.K.

Clarke, S.F., P.L. Guy, D.J. Burritt, and P.E. Jameson. 2002. Changes in the activities of antioxidant enzymes in response to virus infection and hormone treatment. Physiol. Plant. 114:157-164.

Costa,H., M. Susana, S.M. Gallego, and M.L. Tomaro. 2002. Effect of UV-B radiation on antioxidant defense system in sunflower cotyledons. Plant Sci. 162:939-945.

Day, T.A., T.C. Vogelmann, and E.H. DeLucia. 1992. Are some plant life forms more effective than others in screening out ultraviolet-B radiation? Oecologia 92:513-519.

Ervin, E.H., X. Zhang, and J.H. Fike. 2004. Ultraviolet-B radiation damage on kentucky bluegrass. I. Antioxidant and colorant treatments. HortScience 39(6):1467-1472.

Field,T.S.,D.W.Lee, and N.M.Holbrook. 2001.Why leaves turn red in autumn. The role of anthocyanins in senescing leaves of red-osier dogwood. Plant Physiol. 127:566-574.

Gausman, H.W., R.P. Rodriguez, and D.E. Escobar. 1975. Ultraviolet radiation reflectance, transmittance, and absorbance by plant leaf epidermises. Agron. J. 83:391-396.

Giannopolitis, C.N. and S.K. Ries. 1977. Superoxide dismutase. I. Occurrence in higher plants. Plant Physiol. 59:309-314.

Giese,M.S., Gaussoin, R.E., Shearman, R.C., andT.P. Riordan. 1997. Sod production characteristics of turf-type Buchloë dactyloides. Intl. Turfgrass Soc. Res. J. 8:455-465.

Gillham, D. and A. Dodge. 1987. Chloroplast superoxide and hydrogen peroxide scavenging systems from pea leaves: Seasonal variations. Plant Sci. 50:105-109.

Hamada, A.M. 1998. Effects of exogenously added ascorbic acid, thiamin or aspirin on photosynthesis and some related activities of drought-stressed wheat plants, p. 2581-2584. In: G. Garab (ed.). Photosynthesis: Mechanisms and effects. vol. 4. Kluwer Academic Publ., Dordrecht, The Netherlands.

Heckman, N.L., G.L. Horst, R.E. Gaussoin, and K.W. Frank. 2001. Storage and handling characteristics of trinexapac-ethyl treated kentucky bluegrass sod. HortScience 36:1127-1130.

Holton, T.A. and E.C. Cornish. 1995. Genetics and biochemistry of anthocyanin biosynthesis. Plant Cell 7:1071-1083.

Jiang, Y.L., W.Z. Lan, W.M. Qin, H.B. Xu, and L.J. Yu. 2001. Effects of salicylic acid on fungal elicitor-induced membrane lipid peroxidation and taxol production in cell suspension cultures of Taxus chinensis. Process Biochem. 37:477-482.

Jordan, B.P. 1996. The effects of ultraviolet-B radiation on plants: A molecular perspective. Adv. Bot. Res. 22:97-162.

King J.W., J.B. Beard, and P.E. Rieke. 1982. Factors affecting survival of kentucky bluegrass sod under simulated shipping conditions. J.Amer. Soc. Hort. Sci. 107:634-637.

Larkindale, J. and M.R. Knight. 2002. Protection against heat stress-induced oxidative damage in Arabidopsis involves calcium, abscisic acid, ethylene, and salicylic acid. Plant Physiol. 128:682-695.

Leshem.Y.Y. 1981. Oxy free radicals and plant senescence. What's New in Plant Physiol. 12(1):1-4.

Liu, X.Z. and B.R. Huang. 2002. Cytokinin effects on creeping bentgrass response to heat stress: II. Leaf senescence and antioxidant metabolism. Crop Sci. 42: 466-472.

Mackerness, S.A.H. 2000. Plant responses to ultraviolet-B (UV-B: $280-320 \mathrm{~nm}$ ) stress: What are the key regulators? Plant Growth Regulat. 32:27-39.

Maibangsa, S., M. Thangaraj, and R. Stephen. 2000. Effect of brassinosteroid and salicylic acid on rice (Oryza sativa L.) grown under low irradiance condition. Indian J. Agr. Res. 34:258-260.

Malamy, J. and D.F. Klessig. 1992. Salicylic acid and plant disease resistance. The Plant J. 2:643-654

Muscolo, A., S. Cutrupi, and S. Nardi. 1998. IAA detection in humic substances. Soil Biol. Biochem. 30:1199-1201.

Musgrave, M.E. 1994. Cytokinins and oxidative processes, p.167-178. In: D. Mok and M. Mok (eds.). Cytokinins: Chemistry, activity, and function. CRC Press, Boca Raton, Fla.

Nakano, Y. and K. Asada. 1981. Hydrogen peroxide is scavenged by ascorbate-specific peroxidase n spinach chloroplasts. Plant Cell Physiol. 22:867-880.

Nooden, L.D. and A.C. Leopold. 1988. Senescence and aging in plants. Academic Press, London.

Noorudeen, A.M. and G. Kulandaivelu. 1982. On the possible site of inhibition of photosynthetic electron transport by ultraviolet-B (UV-B) radiation. Physiol. Plant. 55:161-166.

Perez-Rodriguez, E., I. Gomez, U. Karsten, and F.L. Figueroa. 1998. Effects of UV radiation on photosynthesis and excretion of UV-absorbing compounds of Dasycladus vermicularis (Dasycladales, chlorophyta) from southern Spain. Phycologia 37:379-387.

Polle, A. 1997. Defense against photooxidative damage in plants, p. 623-666. In: J.G. Scandalios (ed.). Oxidative stress and the molecular biology of antioxidant defenses. Cold Spring Harbor Lab Press, Plainview, N.Y.

Rabino, I. and A.L. Mancinelli. 1986. Light, temperature, and anthocyanin production. Plant Physiol. 81:922-924.

Rao, M.V., G. Paliyath, and D.P. Ormrod. 1996. Ultraviolet-B and ozone-induced biochemical changes in antioxidant enzymes of Arabidopsis thaliana. Plant Physiol. 110:125-136.

Salisbury, F.B. and C.W. Ross. 1991. Plant Physiology, $4^{\text {th }}$ ed. Wadsworth Publ. Co., Belmont Calif.

Sanderson, K.J., P.E. Jameson, and J.A. Zabkiewicz. 1987. Auxin in a seaweed extract: Identification and quantitation of indole-3-acetic acid by gas chromatography-mass spectrometry. J. Plant
Physiol. 129:363-367.

Sanjay, G., B.S. Sohal, K.L. Bajaj, A.P.S. Mann, and S. Guleria. 2001. Elicitation of enzyme activity and phenols by salicylic acid and gamma aminobutyric acid in pea leaves. Plant Dis. Res. $16: 158-165$.

SAS Institute Inc. 1988. SAS/STAT use's guide. Release 6.03 ed. SAS Institute Inc., Cary, N.C.

Schmidt, R.E. and X. Zhang. 2001. Alleviation of photochemical activity decline of turfgrasses exposed to soil moisture stress or UV radiation. Intl. Turfgrass Res. J. 9:340-346.

Shehata, S.A.M., S.I. Ibrahim, and A.M.Z. Sanaa 2001. Physiological response of flag leaf and ears of maize plant induced by foliar application of kinetin (Kin) and acetyl salicylic acid (ASA). Ann. Agr. Sci. Cairo 46:435-449.

Singh, A.B. 2001. Influence of phenolic pompounds on yield and protein quality of green gram (Vigna radiata L. Wilczek). Legume Res. 24:260-263.

Singhvi, N.R., J. Kodandaramaiah, M. Rekha, A. Sarkar, and R.K. Datta. 2001. Effect of salicylic acid on leaf yield and pigment content in mulberry (Morus spp.). Indian J. Sericult. 40:100-102.

Strid, A. and R.J. Porra. 1992. Alterations in pigment content in leaves of Pisum sativum after exposure to supplementary UV-B. Plant Cell Physiol. 33:1015-1023.

Strid A., W.S. Chow, and J. Anderson. 1990. Effects of supplementary ultraviolet-B radiation on photosynthesis in Pisum sativum. Biochim. Biophys. Acta. 1020:260-268.

Tanaka, K., R. Masuda, T. Sugimato, K. Omasa, and T. Sakasi. 1990. Water deficiency-induced changes in the contents of defensive substances against active oxygen in spinach leaves. Agr. Biol. Chem. 54:2629-2634.

Teramura, A.H. 1996. Ultraviolet-B radiation and photosynthesis, p. 435-450. In: N.R. Baker (ed.). Photosynthesis and the environment. Kluwer Academic Publ., Dordrecht, The Netherlands.

Yan, J., R.E. Schmidt, and D.M. Orcutt. 1997. Influence of fortified seaweed extract and drought stress on cell membrane lipids and sterols of ryegrass leaves. Intl. Turfgrass Soc. Res. J. 8:1356-1362.

Yan, J.Y. 1993. Influence of plant growth regulators on turfgrass polar lipid composition, tolerance to drought and salinity stress, and nutrient efficiency. PhD diss. Va. Polytech. Inst. State Univ., Blacksburg (Diss. Abstr. 93 16828).

Young, C.C. and L.F. Chen. 1997. Polyamines in humic acid and their effect on radical growth of lettuce seedlings. Plant and Soil 195:143-149.

Zhang, X. and E. Ervin. 2004. Cytokinin-containing seaweed and humic acid extracts associated with creeping bentgrass leaf cytokinins and drought resistance. Crop Sci. (in press).

Zhang, X., E. Ervin, and R.E. Schmidt. 2003. Plant growth regulators can enhance the recovery of kentucky bluegrass sod from heat injury. Crop Sci. 43(3)952-956.

Zhang, J. and M.B. Kirkham. 1994. Drought-stressinduced changes in activities of superoxide dismutase, catalase, and peroxidase in wheat species Plant Cell Physiol. 35:785-791.

Zhang, X. and R.E. Schmidt. 1997. The impact of growth regulators on the alpha-tocopherol status in water-stressed Poa pratensis. Intl. Turfgrass Res. J. 8:1364-1371.

Zhang, X. and R.E. Schmidt. 1999. Antioxidant responses to hormone-containing products in kentucky bluegrass subjected to drought. Crop Sci. 39:545-551.

Zhang, X. and R.E. Schmidt. 2000. Application of trinexapac-ethyl and propiconazole enhances superoxide dismutase and photochemical activity in creeping bentgrass. (Agrostis stoloniferous var. palustris). J. Amer. Soc. Hort. Sci. 125:47-51. 